\title{
Exposure of iron foundry workers to polycyclic aromatic hydrocarbons: benzo(a)pyrene-albumin adducts and 1-hydroxypyrene as biomarkers for
} exposure

\author{
$\varnothing$ Omland, D Sherson, Å M Hansen, T Sigsgaard, H Autrup, E Overgaard
}

Department of Occupational Medicine, Aarhus University Hospital, Denmark $\varnothing$ Omland

Department of Occupational Medicine, Vejle County Hospital, Denmark

D Sherson

E Overgaard

Department of

Chemistry and

Biochemistry,

National Institute of

Occupational Health,

Denmark

Å M Hansen

Steno Institute of Public Health, Department of Environmental and Occupational Medicine, University of Aarhus, Denmark $\varnothing$ Omland

T Sigsgaard

H Autrup

Correspondence to: Dr Ø Omland, Department of Environmental and Occupational Medicine, University of Aedicine, University of Aarhus, Universitetsparken, Buildin Denmark.

Accepted 19 April 1994

\section{Abstract}

Exposure to polycyclic aromatic hydrocarbons (PAHs) in foundry workers has been evaluated by determination of benzo(a)pyrene-serum albumin adducts and urinary 1-hydroxypyrene. Benzo(a)pyrene binding to albumin and 1-hydroxypyrene were quantitatively measured by enzyme linked immunosorbent assay (ELISA) and reverse phase high performance liquid chromatography (HPLC), respectively. 70 male foundry workers and 68 matched controls were investigated. High and low exposure groups were defined from breathing zone hygienic samples, consisting of $16 \mathrm{PAH}$ compounds in particulate and gaseous phase. Mean total PAH was $10 \cdot 40 \mu \mathrm{g} / \mathrm{m}^{3}$ in the breathing zone, and mean dust adsorbed PAH was $0.15 \mu \mathrm{g} / \mathrm{m}^{3}{ }^{3}$ All carcinogenic PAH was adsorbed to dust. Median benzo(a)pyrene-albumin adduct concentrations (10-90\% percentiles) were similar in foundry workers (smokers 0.55 $(0 \cdot 27-1 \cdot 00)$ and non-smokers 0.58 (0.171.15)) $\mathrm{pmol} / \mathrm{mg}$ albumin and age matched controls (smokers $0.57(0.16-1.45)$ and non-smokers $0 \cdot 70 \quad(0 \cdot 19-1 \cdot 55) \quad \mathrm{pmol} / \mathrm{mg}$ albumin). Median 1-hydroxypyrene concentrations were significantly higher $(P<$ 0.0001 ) in smoking and non-smoking foundry workers $(0.022(0.006-0.075)$ and $0 \cdot 027(0 \cdot 006-0 \cdot 164)) \mu \mathrm{mol} / \mathrm{mol}$ creatinine than in smoking and non-smoking controls (0 (0-0.022) and $0(0-0.010) \mu \mathrm{mol} / \mathrm{mol}$ creatinine). Dose-response relations between total PAH, pyrene, carcinogenic PAHs, and 1-hydroxypyrene for smokers, and polycyclic aromatic hydrocarbons adsorbed to dust for non-smokers are suggested. Exposure to PAHs adsorbed to dust showed an additive effect. There was no correlation between the concentrations of 1-hydroxypyrene and benzo(a)pyrene-albumin adducts. The change in 1-hydroxypyrene over a weekend was also studied. Friday morning median 1-hydroxypyrene concentrations were significantly higher in both smokers and non-smokers $(0.021 \quad(0-0.075)$ and $0.027(0.006-0.164)) \mu \mathrm{mol} / \mathrm{mol}$ creatinine than Monday morning median concentrations $(0.007 \quad(0-0.021)$ and 0.008 $(0-0 \cdot 021) \mu \mathrm{mol} / \mathrm{mol}$ creatinine). Smoking did not affect the concentrations of 1-hydroxypyrene or benzo(a)pyrene- albumin adducts. These data suggest that 1-hydroxypyrene is a sensitive biomarker for low dose PAH exposure. Exposure to PAHs may be aetiologically related to increased risk of lung cancer in foundry workers.

(Occup Environ Med 1994;51:513-518).

Increased risk of lung cancer has been shown to occur in several studies of iron foundry workers. ${ }^{1-4}$ Polycyclic aromatic hydrocarbons (PAHs) may be an aetiological factor. ${ }^{56}$ Exposure to carcinogenic chemicals (for example PAHs) can be evaluated by measuring covalent binding with macromolecular targets, DNA, and proteins. ${ }^{7}$ As target tissue is not usually available several surrogate materials have been studied-namely, white blood cells, ${ }^{8}$ lymphocytes, ${ }^{9}$ and serum proteins. ${ }^{1011}$ 1-Hydroxypyrene, a urinary metabolite of pyrene, has recently been used as to monitor PAH exposure in humans. ${ }^{12-15}$

In iron foundries PAHs are present in both the gaseous phase and adsorbed on to dust. ${ }^{16}$ Benzo(a)pyrene adsorbed to particles in the lungs may augment carcinogenicity due to increased long term retention. ${ }^{17} 18$ These findings suggest that inhaled PAHs adsorbed to particles covalently interact with macromolecules to a greater extent than gaseous PAHs. ${ }^{19}$

The purpose of this study was to: (a) quantify the concentrations of serum benzo(a)pyrene-albumin adducts and urinary 1-hydroxypyrene in healthy iron foundry workers, $(b)$ investigate possible positive correlations between these biomarkers and PAH exposure variables (total PAHs, particulate PAHs, carcinogenic PAHs, and pyrene), (c) determine whether positive correlations exist between the two biomarkers, and (d) compare Friday and Monday morning 1-hydroxypyrene concentrations.

Subjects and methods STUDY POPULATION AND CONTROL GROUP The study population consisted of 70 male iron foundry workers. They were employed in melting, machine moulding, casting, or sand preparation. All were occupationally exposed to PAHs. The foundry was located in a small Danish town. The control group consisted of 68 male blue collar workers from a drinking water supply plant near Copenhagen, all 
Table 1 Comparison of control and exposed groups

\begin{tabular}{|c|c|c|}
\hline & $\begin{array}{l}\text { Control group } \\
\text { (water supply } \\
\text { workers) } \\
(n=68)\end{array}$ & $\begin{array}{l}\text { Exposed group } \\
\text { (foundry workers) } \\
(n=70)\end{array}$ \\
\hline \multirow{2}{*}{$\begin{array}{l}\text { Smokers } \\
\text { Age (y) } \\
\text { Age range (y) } \\
\text { Pack-years } \\
\text { Urinary creatinine } \\
\text { (mmol/l) }\end{array}$} & $\begin{array}{l}(n=42) \\
43 \\
24-66 \\
18(11)\end{array}$ & $\begin{array}{l}(n=45) \\
40 \\
24-63 \\
16(13)\end{array}$ \\
\hline & $11 \cdot 3(4 \cdot 3)$ & $17 \cdot 8(6 \cdot 9)$ \\
\hline \multirow{2}{*}{$\begin{array}{l}\text { Non-smokers } \\
\text { Age (y) } \\
\text { Age range (y) } \\
\text { Urinary creatinine } \\
(\mathrm{mmol} / \mathrm{l})\end{array}$} & $\begin{array}{l}(\mathrm{n}=26) \\
43 \\
26-64\end{array}$ & $\begin{array}{l}(n=25) \\
43 \\
24-60\end{array}$ \\
\hline & $13 \cdot 1(6 \cdot 2)$ & $19 \cdot 6(6 \cdot 8)$ \\
\hline
\end{tabular}

All workers were men. Values are mean (SD) unless stated otherwise.

occupationally unexposed to PAHs. These groups were matched for age and smoking habits (table 1). Information about employment, smoking, alcohol consumption, respiratory and urogenital symptoms, and medications including the use of coal tar salves were obtained from questionnaires and checked by personal interviews. Tobacco, cigars, and cheroots smoked were translated to cigarettes when calculating pack-years. ${ }^{20}$ The research protocol was accepted by the local ethics committee.

\section{EXPOSURE GROUP AND AIR SAMPLING}

Foundry workers were subdivided into low and high PAH exposure groups based on breathing zone measurements $(n=17)$ : (1) total PAH: low $<10.00 \mu \mathrm{g} / \mathrm{m}^{3}$; high $\geqslant 10.00$ $\mu \mathrm{g} / \mathrm{m}^{3}$ (2) particulate PAH: low $<0.21 \mu \mathrm{g} / \mathrm{m}^{3}$ high $\geqslant 0.21 \mu \mathrm{g} / \mathrm{m}^{3}$ (3) carcinogenic PAH: low $<0.10 \mu \mathrm{g} / \mathrm{m}^{3}$; high $\geqslant 0.10 \mu \mathrm{g} / \mathrm{m}^{3}$ and (4) pyrene: low $<0 \cdot 10 \mu \mathrm{g} / \mathrm{m},{ }^{3}$ high $\geqslant 0.10 \mu \mathrm{g} / \mathrm{m} .^{3}$

The sample preparation and steps of reversed phase high performance liquid chromatography (HPLC) have previously been described in detail ${ }^{21-23}$ and are only summarised here. Air samples (600-800 1) were collected at a flow rate of $1.9 \mathrm{l} / \mathrm{min}$ during the work shift (about seven hours). Particulates were collected on a $37 \mathrm{~mm}$ glass fibre filter (Millipore AP 4003-705) in a standard cassette of polystyrene, and gaseous PAH compounds on a PVC tube in series with a styrene-divinylbenzene adsorption tube. The concentration of 16 selected PAH compounds $^{24}$ was measured by comparison with the chromatogram of standard PAH preparations. Total PAH concentration was calculated as the sum of the particulate and gaseous concentrations. Total particulate concentration was calculated as the sum of the compounds attached to the glass fibre filter. The total concentration of carcinogenic compounds was calculated as the sum of the concentrations of benzo(a)anthracene, benzo(b)fluoranthene, benzo(k)fluoranthene, benzo(a)pyrene, dibenz(a,h)anthracene, and indeno $(1,2,3-\mathrm{cd})$ pyrene. ${ }^{25}$

\section{BLOOD COLLECTION}

Blood samples $(10 \mathrm{ml})$ were collected from exposed subjects on a Friday morning in April 1989. The blood was allowed to coagulate overnight at $4^{\circ} \mathrm{C}$. The coagulum was removed after centrifugation at $3000 \mathrm{rpm}$. The serum samples were frozen at $-20^{\circ} \mathrm{C}$ until analysed.

\section{ANALYSIS OF BENZO(a)PYRENE-ALBUMIN}

ADDUCTS IN BLOOD SAMPLES

The level of benzo(a)pyrene-albumin adducts was detected by competitive enzyme linked immunosorbent assay (ELISA) as previously described. ${ }^{10}{ }^{26}$ Serum $(2 \mathrm{ml})$ was isolated from the blood samples by centrifugation, and albumin was precipitated by addition of saturated ammonium sulphate (final concentration $50 \%$ ). After removal of globulins by centrifugation, albumin was precipitated from the supernatant by acidification with acetic acid.

Albumin was redissolved in $500 \mu \mathrm{l}$ of $0 \cdot 1 \mathrm{M}$ sodium phosphate buffer, $\mathrm{pH} \mathbf{7 \cdot 4}$, and digested by pronase. The concentration of albumin was determined by Biuret reagent assay. The digest was applied to a prewet $\mathrm{C} 18$ Sepak column. The column was washed with $5 \mathrm{ml}$ of $5 \%$ methanol to remove small peptides and amino acids. The PAH metabolites were eluted with $80 \%$ methanol $(5 \mathrm{ml})$ and the eluate was evaporated to $500 \mu \mathrm{l}$ in a vacuum.

\section{COMPETITIVE ELISA}

Polystyrene 96 microwell plates (NUNC immunoplates, Nunc, Roskilde, Denmark) were coated with 7,8-dihydroxy-9,10-epoxy7,8,9,10-tetrahydrobenzo(a)pyrene (BPDE) modified dextran. The competitive antigen was diluted $1: 10$ and $1: 100$ in phosphate buffered saline (PBS), and $100 \mu \mathrm{1} /$ well (five wells for each dilution) was added, followed by the primary antibody 8E11 (kindly provided by Dr $R$ Santella, Columbia University, NY, USA) diluted 1:250 000 in PBS (100 $\mu \mathrm{l} /$ well). A series of different concentrations of hydrolysed BPDE (0.1 fM to $1.0 \mathrm{pM}$, four wells for each concentration) were included in each plate. The level of modification was estimated from the standard curve with the 1:1000 dilution of the competitive antigen, and was expressed as pmol BPDE/mg albumin. The competitive assay has been described in detail elsewhere. ${ }^{27}$

Antibody 8E11, which detects BPDEs, released by acid hydrolysis of proteins, also recognises benzo(a)pyrene diols, triols, and tetrols and cross reacts with several other PAHs, with different affinities. ${ }^{1011}$ Consequently results are expressed as benzo(a)pyrene equivalents that correspond to the amount of BPDE necessary to give the same level of inhibition.

\section{URINE COLLECTION AND DETERMINATION OF} 1-HYDROXYPYRENE AND CREATININE

The urine samples from foundry workers were collected as the second urinary voids on Friday morning and the following Monday morning in April 1989, and frozen at $-20^{\circ} \mathrm{C}$ until analysed. Urinary creatinine was measured to standardise the results. ${ }^{28}$

The sample preparation and chromatography have been previously described in 
detail. $^{21} 29$ The standard plot was linear for the concentration range of the standard curve. Urine samples $(10.0 \mathrm{ml})$ were buffered with $10.0 \mathrm{ml} 0.2 \mathrm{~N}$ sodium acetate buffer ( $\mathrm{pH} 5.0$ ) and hydrolysed enzymatically with $200 \mu \mathrm{l}$ $\beta$-glucuronidase/sulphatase (26 $400 \mathrm{U} \beta$-glucuronidase and $440 \mathrm{U}$ sulphatase) for 20 hours at $37.5^{\circ} \mathrm{C}$ in a shaking water bath. After hydrolysis the sample was centrifuged for 10 minutes at $3000 \mathrm{rpm}(928 \mathrm{~g})$ at ambient temperature. Samples of the standard solution and the centrifuged sample were applied to a Bond Elute sample enrichment and purification cartridge packed with C-18 (Varian, Harbor City, CA, USA). The cartridge was primed with $2.5 \mathrm{ml}$ acetonitrile, followed by $10 \mathrm{ml}$ water, and the hydrolysed sample was passed through the cartridge at a flow rate of $2.5 \mathrm{ml} / \mathrm{min}$. Subsequently, the cartridge was washed with $5 \mathrm{ml} 0 \cdot 2 \mathrm{~N}$ sodium acetate buffer (pH 5.0). The retained solutes were eluted with $1.5 \mathrm{ml}$ acetonitrile. Samples of $25 \mu \mathrm{l}$ of the final extracts were injected into the HPLC column.

\section{STATISTICAL ANALYSIS}

Data were analysed with the statistical package for social sciences (SPSS). ${ }^{30}$ Statistical methods comprised Student's $t$ test and nonparametric tests for paired and non-paired data. ${ }^{3132}$ All tests were two tailed.

\section{Results}

The mean (SD) total PAH concentration was $10.40(4.04) \mu \mathrm{g} / \mathrm{m}^{3}$ The mean dust adsorbed PAH concentration was $0.15(0.21)$ representing $1.44 \%$ of the total PAH concentration. Table 2 shows the mean concentrations of the 16 standard PAHs in gaseous and particulate forms. Four of the six carcinogenic PAHs were measurable in the dust adsorbed form only. Pyrene was found in both phases.

Figure 1 shows the median values for 1hydroxypyrene concentrations from exposed workers and controls. Smoking and nonsmoking foundry workers had significantly increased 1-hydroxypyrene concentrations compared with their control counterparts. The median values (10-90\% percentiles) for the four groups were $0.022(0.006-0.075)$, $0.027(0.006-0.164), 0(0-0.022)$, and 0

Table 2 Mean (SD) concentrations of 16 gaseous and particulate PAHs

\begin{tabular}{|c|c|c|c|}
\hline$P A H$ & $\begin{array}{l}\text { Particulate PAHs } \\
\left(\mu g / m^{3}\right)\end{array}$ & $\begin{array}{l}\text { Gaseous PAHs } \\
\left(\mu g / m^{3}\right)\end{array}$ & $\begin{array}{l}\text { Total PAHs } \\
\left(\mu g / m^{3}\right)\end{array}$ \\
\hline 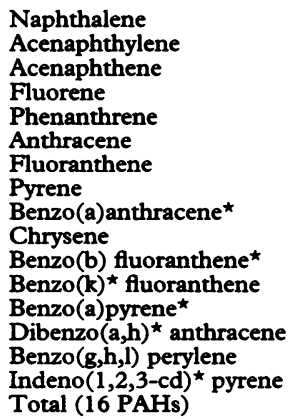 & $\begin{array}{l}0(0) \\
0(0) \\
0(0) \\
0.004(0.01) \\
0.01(0.04) \\
0.01(0.02) \\
0.02(0.07) \\
0.004(0.01) \\
0.01(0.02) \\
0.02(0.03) \\
0.003(0.01) \\
0.02(0.04) \\
0.02(0.04) \\
0(0) \\
0.05(0.08) \\
0(0) \\
0.15(0.21)\end{array}$ & $\begin{array}{l}9.68(3.85) \\
0(0) \\
0.03(0.17) \\
0.08(0.05) \\
0.31(0.16) \\
0.04(0.03) \\
0.11(0.15) \\
0.01(0.02) \\
0(0) \\
0(0) \\
0(0) \\
0(0) \\
0(0) \\
0(0) \\
0(0) \\
0(0) \\
10.24(4.03)\end{array}$ & $\begin{array}{l}9.68(3.85) \\
0(0) \\
0.03(0.17) \\
0.08(0.05) \\
0.32(0.17) \\
0.05(0.03) \\
0.13(0.20) \\
0.01(0.03) \\
0.01(0.02) \\
0.02(0.03) \\
0.003(0.04) \\
0.02(0.04) \\
0.02(0.04) \\
0(0) \\
0.05(0.08) \\
0(0) \\
10.40(4.04)\end{array}$ \\
\hline
\end{tabular}

${ }^{\star}$ Carcinogenic PAHs. Seventeen measurements were taken.

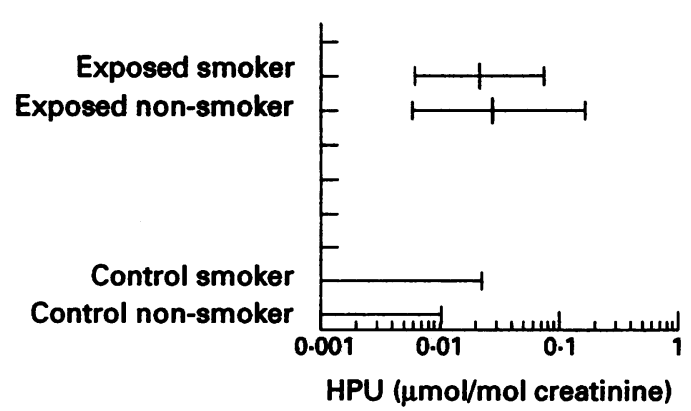

Figure 1 Median corrected 1-hydroxypyrene (HPU) concentrations with 10-90\% percentiles for foundry workers and controls.

$P<0.0001$ smoking and non-smoking exposed workers $v$ smoking and non-smoking controls (Mann-Whitney $U$ test).

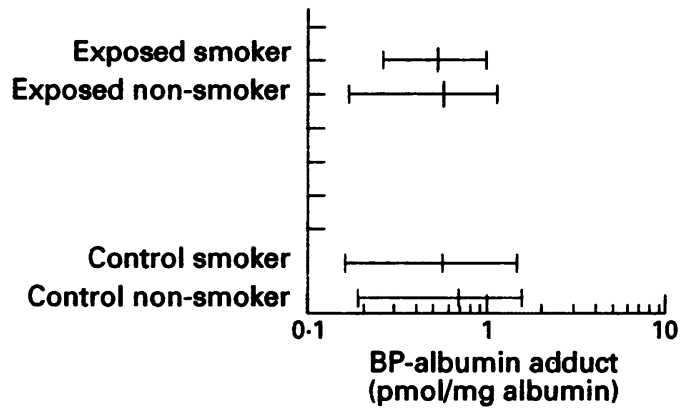

Figure 2 Median benzo(a)pyrene-albumin adduct concentrations with 10-90\% percentiles for foundry workers and controls.

$P=0.20$ non-smoking exposed workers $v$ non-smoking controls; $P=0.65$ smoking exposed workers $v$ smoking controls (Mann-Whitney U test).

$(0-0.010) \mu \mathrm{mol} / \mathrm{mol}$ creatinine respectively. There was no significant difference in 1hydroxypyrene concentration between smokers and non-smokers in the exposed or the control groups $(P$ exposed $=0.53, P$ unexposed $=0.06$ ).

Figure 2 illustrates the median benzo(a)pyrene-albumin adduct concentrations in blood from foundry workers and controls. The adduct concentrations were not increased in either smoking or non-smoking foundry workers, compared with smoking and nonsmoking controls $(\mathrm{P}$ smokers $=0.65, \mathrm{P}$ nonsmokers $=0 \cdot 20$ ). The median values for the four groups were $0.55(0.27-1.00), 0.58$ $(0 \cdot 17-1 \cdot 15), 0.57(0.16-1 \cdot 45)$, and 0.70 $(0 \cdot 19-1 \cdot 55) \mathrm{pmol} / \mathrm{mg}$ albumin respectively. No difference in benzo(a)pyrene-albumin adduct concentrations was found between smokers and non-smokers in either the exposed or the control group ( $P$ exposed $=$ $0.99, \mathrm{P}$ unexposed $=0.22$ ).

No correlations were found between any of the PAH exposure variables (total PAHs, particulate PAHs, carcinogenic PAHs, and pyrene) and median benzo(a)pyrene-albumin adduct concentrations in the blood, either for smokers or for non-smokers. Regression analyses showed no correlations between concentration of 1-hydroxypyrene and albumin adducts $\left(R^{2}=5 \times 10^{-5}\right)$.

Figure 3 shows median 1-hydroxypyrene concentrations according to total PAH exposure for smokers and non-smokers. Smoking 
Figure 3 Median corrected 1-hydroxypyrene (HPU) concentrations with $10-90 \%$ percentiles for controls and foundry workers according to low and high exposure to total $P A H$.

$P<0.0001$ low and high smoking and non-smoking exposed workers compared with smoking and nonsmoking controls (MannWhitney $U$ test).

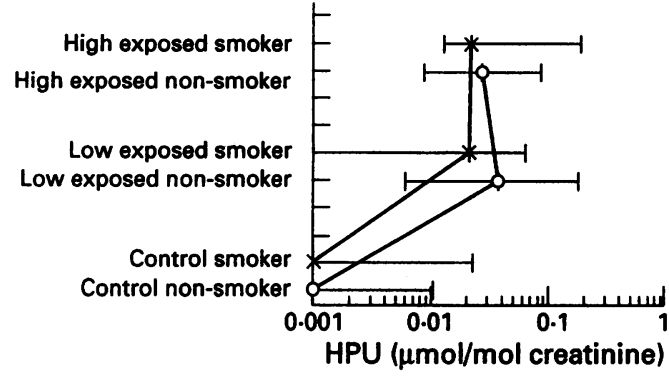

foundry workers in both low and high total PAH exposure groups had significantly higher concentrations than smoking controls. The median values for the three groups were 0.020 $(0-0.062), 0.022(0.012-0.180)$, and 0 (0-0.022) $\mu \mathrm{mol} / \mathrm{mol}$ creatinine respectively. Non-smoking foundry workers also had significantly higher 1-hydroxypyrene concentrations than non-smoking controls. High exposure foundry workers had slightly lower 1-hydroxypyrene concentrations than low exposure workers. The median values were $0.026(0.008-0.083), 0.036(0.006-0.174)$, and $0(0-0.018) \mu \mathrm{mol} / \mathrm{mol}$ creatinine respectively.

Figure 4 shows the median 1-hydroxypyrene concentrations and exposure to particulate PAH for smokers and non-smokers. Non-smoking foundry workers with low or high exposures to dust adsorbed $\mathrm{PAH}$ had significantly higher concentrations of 1-hydroxypyrene than non-smoking controls. The median values for the three groups were 0.026 $(0.004-0.164), 0.036(0.006-0.062)$, and 0 $(0-0.010) \mu \mathrm{mol} / \mathrm{mol}$ creatinine respectively. Both low and high exposure foundry workers who smoked had significantly higher concentrations of 1-hydroxypyrene than smoking controls. High exposure workers had slightly lower 1-hydroxypyrene concentrations than low exposure workers. The median values were $0.020(0-0.057), 0.023(0.001-0.178)$, and $0(0-0.022) \mu \mathrm{mol} / \mathrm{mol}$ creatinine.

The median 1-hydroxypyrene concentrations according to exposure to carcinogenic PAHs and pyrene showed the same relation as for total PAHs. Both smoking and nonsmoking foundry workers had significantly higher concentrations of 1-hydroxypyrene than their control counterparts ( $P$ low < $0.0001, \mathrm{P}$ high $<0.0001)$. For both exposure variables smokers showed dose-response relations whereas non-smokers did not.

Figure 5 shows Friday and Monday morning median 1-hydroxypyrene concentrations.

Figure 4 Median corrected 1-hydroxypyrene (HPU) concentrations with $10-90 \%$ percentiles for controls and foundry workers according to low and high exposure to dust adsorbed PAHs.

$P<0.0001$ low and high smoking and non-smoking exposed workers $v$ smoking and non-smoking controls (Mann-Whitney $U$ test).

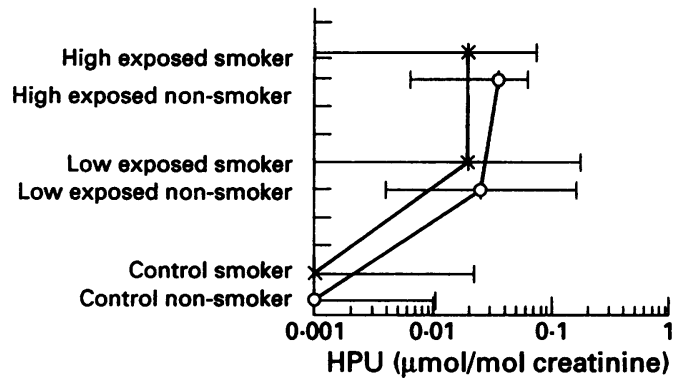

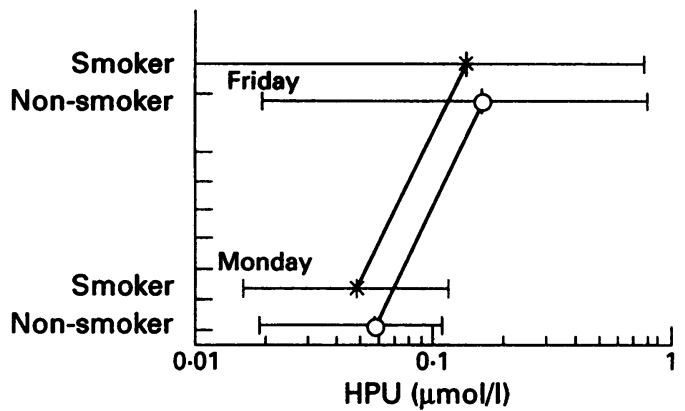

Figure 5 Median 1-hydroxypyrene (HPU) Friday and Monday morning concentrations with $10-90 \%$ percentiles for foundry workers.

$P<0.01$ smokers and non-smokers Friday HPU $v$ smokers and non-smokers Monday HPU (Wilcoxon rank sum $W$ test).

Concentrations of 1-hydroxypyrene on Friday morning were significantly higher for both smokers and non-smokers than on Monday morning. The median Friday values were $0.021(0-0.075)$ and $0.027(0.006-0.164)$ $\mu \mathrm{mol} / \mathrm{mol}$ creatinine and Monday values were $0.007 \quad(0-0.021)$ and $0.008 \quad(0-0.021)$ $\mu \mathrm{mol} / \mathrm{mol}$ creatinine.

\section{Discussion}

The mean total PAH exposure in this foundry, $10.40 \mu \mathrm{g} / \mathrm{m}^{3}$, is higher than the mean exposure recently described in another Danish foundry, ${ }^{10}{ }^{21}$ but lower than the mean exposure in German foundries $(17.54$ $\left.\mu \mathrm{g} / \mathrm{m}^{3}\right) \cdot{ }^{16}$ Similar exposure levels, $\left(8 \cdot 32 \mu \mathrm{g} / \mathrm{m}^{3}\right)$ have been found in roofers. ${ }^{33}$

The mean concentration in our study of both benzo(a)pyrene $\left(0.01 \mu \mathrm{g} / \mathrm{m}^{3}\right)$ and pyrene $\left(0.01 \mu \mathrm{g} / \mathrm{m}^{3}\right)$ was lower than previously described in another Danish foundry $(0.04$ and $\left.0.28 \mu \mathrm{g} / \mathrm{m}^{3}\right)^{10}$ and considerably lower than the mean concentration found in the German study $\left(0.47\right.$ and $\left.1.47 \mu \mathrm{g} / \mathrm{m}^{3}\right) .{ }^{16}$ The range of concentrations in 10 Canadian foundries for benzo(a)pyrene $(0.004-8.15$ $\mu \mathrm{g} / \mathrm{m}^{3}$ ) and pyrene (up to $12.93 \mu \mathrm{g} / \mathrm{m}^{3}$ ) reflects a much higher exposure. ${ }^{34}$ Recent Finnish studies have described a high exposure group with benzo(a)pyrene five times greater than ours $\left(\geqslant 0.04 \mu \mathrm{g} / \mathrm{m}^{3}\right)$, thus indicating a substantially higher exposure in Finnish foundries. ${ }^{811}$

The mean PAH adsorbed on dust was $1.44 \%$ of the measured total PAH concentration. This ratio is considerably lower than in German foundries, where the PAH adsorbed on dust was $23.20 \%$ of the total PAH concentration. ${ }^{16}$

The reasons for these differences are uncertain, but may reflect different sampling methods, different binding materials, heterogenous hygienic conditions, ${ }^{10}$ and seasonal differences in air sampling. ${ }^{34}$

As reported by others ${ }^{35}$ we found that all carcinogenic PAHs were adsorbed on dust. This might be important considering the prolonged retention of particulate PAHs found in animal studies. ${ }^{17-19}$

In our study, the level of albumin adducts was similar in the exposed and the control 
groups. Significantly raised protein adduct concentrations were found in Danish foundry workers. $^{10}$ Two Finnish studies ${ }^{811}$ found higher concentrations of adducts in occupationally exposed foundry workers than in controls, but the increases were only slight in one study. ${ }^{11}$ In these three studies ${ }^{810} 11$ the exposure to airborne benzo(a)pyrene was considerably higher than in our foundry and may explain why our present study did not find differences.

1-Hydroxypyrene in urine has been used as a biomarker in studying occupational exposure to PAHs in paving workers, ${ }^{13}$ coke oven workers, ${ }^{14}$ and foundry workers. ${ }^{15}$ The results of these studies indicate that 1-hydroxypyrene might be used not only as a marker for exposure to pyrene, but also to assess general PAH exposure. Dutch studies of coke oven workers $^{1436}$ found a more than 10-fold increased concentration of 1-hydroxypyrene in exposed workers, and a twofold increase in benzo(a)pyrene-DNA adduct. The present study confirms that 1-hydroxypyrene is a sensitive biomarker for exposure to PAHs.

There was no indication of a smoking effect on 1-hydroxypyrene concentrations in this study although an effect has been reported elsewhere. ${ }^{101415}$ Others have shown similar 1hydroxypyrene concentrations for smokers and non-smokers. ${ }^{37} \mathrm{~A}$ recent study ${ }^{38}$ concluded that smoking increased the excretion of 1-hydroxypyrene, but it was not a strong determinant.

Our data showed that foundry workers with high exposure to PAHs had similar or only slightly greater 1-hydroxypyrene concentrations than foundry workers with low exposure. This suggests a limited exposure difference between the two exposure groups. It was interesting to note that the exposure variable PAH adsorbed to dust suggested a doseresponse trend for non-smokers. This might be interpreted as an additional effect from simultaneous exposure to PAH and dust. Similar interpretations have been made from results with a combined PAH and silica exposure index. ${ }^{10}$

The concentration of benzo(a)pyrenealbumin adducts in blood and urinary 1hydroxypyrene in foundry workers did not show any correlation. Possible high air pollutant PAH exposure in our control group might veil a real difference in $\mathrm{PAH}$ exposure between occupationally exposed and occupationally unexposed workers, but this argument does not explain why the two biomarkers fail to mirror each other in the data. The lack of correlation could be due to differences in exposure profiles in the two groups. Unsystematic misclassification tends to reduce the risk estimate to unity, but as long as the exposure variables were identical for the two biomarkers, this possible design error does not present any real explanation. Differences between individuals in uptake, metabolism, and excretion might explain the lack of correlation between the two biomarkers. Another explanation could be that the PAH concentrations found in these foundries is below the threshold for increased benzo(a)pyrene-adduct formation.

The half life of 1-hydroxypyrene ranges from six to 35 hours. ${ }^{14}$ The Friday morning values for both smokers and non-smokers were significantly higher than the corresponding Monday values for the same workers. These results correspond with a study of coke oven workers ${ }^{14}$ in whom the end shift values after three days of exposure were higher than the preshift value.

Several potential confounders have been taken into consideration. Only men were studied. Age and duration of employment were not correlated with concentrations of the biomarkers. There was no correlation between smoking and the concentration of the biomarkers. None of the exposed workers or the controls had been treated with coal tars and no one had psoriasis. The study design did not control for potentially important confounding factors like exposure to airborne PAHs from the controls' working environment and from general outdoor pollution. There was no reason to believe, however, that blue collar workers from the drinking water supply plant should be occupationally exposed to PAH. Values for PAHs in the order of $\mathrm{ng} / \mathrm{l}$ have been measured in drinking water, ${ }^{25}$ so there is a theoretical possibility of a minimal exposure to PAHs from water. The benzo(a)pyrene exposure level at the present foundry is four to five times greater than the highest concentration of benzo(a)pyrene detected in Copenhagen $\left(0.009 \mu \mathrm{g} / \mathrm{m}^{3}\right){ }^{39}$ There are no data measuring the PAH content in outdoor air from the town where the foundry is situated. The community is busy and heavily industrialised. It is therefore likely that the range of outdoor air pollution is similar to that of Copenhagen. Possible differences in $\mathrm{PAH}$ content from drinking water and food ${ }^{25} 40$ as well as liver function might have influenced the results to some degree, but this is likely to have been marginal.

We appreciate the financial support provided by the Danish Health Service Fund.

1 Sherson D, Svane O, Lynge E. Cancer incidence among foundry workers in Denmark. Arch Environ Health 1991; 46:75-81.

2 Becher H, Jedrychowski W, Flak E, Gomola $\mathrm{K}$ Wahrendorf J. Lung cancer, smoking, and employment in foundries. Scand 7 Work Environ Health 1989;15: in foundr

3 Siverstein M, Maizlish N, Park R, Silverstein B, Brodsky L, Mirer F. Mortality among ferrous foundry workers. Am $\mathcal{F}$ Ind Med 1986;10:37-43.

4 Fletcher AC, Ades A. Lung cancer mortality in a cohort of English foundry workers. Scand $\mathcal{f}$ Work Environ Health 1984;10:7-16.

5 Palmer WG, Scott WD. Lung cancer in ferrous foundry workers: a review. Am Ind Hyg Assoc f 1981;42:329-40.

6 International Agency for Research on Cancer. Monographs on the evaluation of the carcinogenic risk of chemicals to humans. Vol 42. Silica and some silicates. Lyon: IARC, 1987.

7 Ehrenberg L, Hiesche KD, Osterman-Golkar S, Wennberg I. Evaluation of genetic risks of alkylating agents: tissue doses in mouse from air contaminated agents: tissue doses in mouse from air contamin

8 Perera FP, Hemminki K, Young TL, Brenner D, Kelly G, Santella RM. Detection of polycyclic aromatic hydrocarbon DNA adducts in white blood cells of foundry workers. Cancer Res 1988;48:2288-91.

9 Haugen A, Becher G, Benestad C, Vahakangas K, Trivers GE, Newman MJ, Harris CC. Determination of polycyclic aromatic hydrocarbons in the urine, benzo(a)pyrene diolepoxide-DNA adducts in lymphocyte DNA, and antibodies to the adducts sera from coke oven 
workers exposed to measured amounts of polycyclic aromatic hydrocarbons in the work atmosphere. Cancer Res 1986;46:4178-83.

10 Sherson D, Sabro P, Sigsgaard T, Johansen T, Autrup H. Biological monitoring of foundry workers exposed to polycyclic aromatic hydrocarbons. Br F Ind Med 1990; 47:448-53.

11 Lee BM, Baoyon Y, Herbert R, Hemminki K, Perera FP, Santella RM. Immunologic measurement of polycyclic aromatic hydrocarbon-albumin adducts in foundry workers and roofers. Scand $\mathcal{f}$ Work Environ Health 1991 17:190-4.

12 Jongeneelen FJ, Bos RP, Anzion RBM, Theuws JLG, Henderson PTh. Biological monitoring of polycyclic aromatic hydrocarbons; metabolites in urine. Scand $f$ Work Environ Health 1986;12:137-43.

13 Jongeneelen FJ, Scheepers PTJ, Groenendijk A, van Aerts LAGJM, Anzion RBM, Bos RP, Veenstra SJ. Airborne concentrations, skin contamination, and urinary metabolite excretion of polycyclic aromatic hydrocarbons among paving workers exposed to coal tar derived road tars. Am Ind Hyg Assoc $\mathcal{F}$ 1988;12:600-7.

14 Jongeneelen FJ, van Leeuwen FE, Oosterink S, Anzion RBM, van der Loop F, Bos RP, van Veen HG. Ambien and biological monitoring of coke oven workers: determinants of the internal dose of polycyclic aromatic hydrocarbons. Br F Ind Med 1990;47:454-61.

15 Sherson D, Sigsgaard T, Overgaard E, Loft S, Poulsen $\mathrm{HE}$, Jongeneelen FJ. Interaction of smoking, uptake of polycyclic aromatic hydrocarbons, and cytochrome polycyclic aromatic hydrocarbons, and cytochrome
P450IA2 activity among foundry workers. Br f Ind Med 1992;49:197-202.

16 Knecht U, Elliehausen H-J, Woitowitz H-J. Gaseous and adsorbed PAH in an iron foundry. Br f Ind Med 1986; 43:834-38

17 Creasia DA, Poggenburg JK, Nettesheim P. Elution of benzo(a)pyrene from carbon particles in the respiratory
tract of mice. $\mathcal{F}$ Toxicol Environ Health 1976;1:967-75.

18 Bond JA, Sun JD, Mitchell CE, Dutcher JS, Wolff RK, McClellan RO. Biological fate of inhaled organic compounds associated with particulate matter. In: Lee SD, Schneider T, Grant LD, Verker PJ, eds. Aerosols. Chelsea, MI: Lewis Publisher, 1986:579-92.

19 Wolff RK, Bond JA, Sun JD, Henderson RF, Harkema JR, Griffith WC, et al. Effects of adsorption of benzo(a)pyrene onto carbon black particles on levels of DNA adduct in lungs of rats exposed by inhalation. Toxicol Appl Pharmacol 1989;97:289-99.

20 Silberschmid M, Sabroe S. Low dose asbestos exposure. Århus: FADL, 1985;65. (In Danish, English summary.)

21 Hansen ÅM, Omland Ø, Poulsen OM, Sherson D Sigsgaard T, Christensen JM, Overgaard E. Correlation between work process related PAH exposure and urinary levels of $\alpha$-naphthol, $\beta$-naphtylamine and 1-hydroxypyrene in iron foundry workers. Int Arch Occup Environ Health 1994;65:385-94.

22 Anderson K, Levin JO, Nielsson CA. Sampling and analysis of particulate and gaseous polycyclic aromatic hydrocarbons from tar sources in the working environment. carbons from tar sources in the
Chemosphere 1983;12:197-207.

23 Hansen A M, Olsen IB, Poulsen OM, Holst E. Validation of high performance liquid chromatography/fluorescence detection method for the simultaneous quantification of fifteen polycyclic aromatic hydrocarbons. Ann Occup Hyg 1991;35:603-11.

24 National Institute of Occupational Safety and Health Manual of analytic methods. No 5506-1. Cincinnati:

25 International Agency for Research on Cancer. Monographs on the evaluation of the carcinogenic risk of chemicals to humans. Vols 32-35. Lyon: IARC, 1983-85.

26 Autrup JL, Schmidt J, Seremet T, Autrup H. Determination of exposure to aflatoxins among Danish workers in animal-feed production through the analysis of aflatoxin B adducts to serum albumin. Scand 7 Work Environ Health 1991;17:436-40.

27 Autrup H, Seremet T, Sherson D. Quantitation of polycyclic aromatic hydrocarbons-serum protein and lymphocyte DNA adducts in Danish foundry workers using immunoassays. In: Garner RC, Farmer FB, Steel GT Wright AS, eds. Human carcinogenic exposure-biomonitoring and risk assessment. Oxford: IPL Press, 1991:207-13.

and risk assessment. Oxford: IPL Press, 1991:207-13.
28 Bartels H, Bohmer M. Eine mikrometode zur kreatinibestimmung. Clin Chim Acta 1971;32:81-5.

29 Hansen $\AA$ M, Poulsen OM, Hansen SH, Christensen JM Determination of 1-hydroxypyrene in urine by high pressure liquid chromatography. Annals of Toxicology 1993;17:1-5. 30 Noruses MJ, ed. Statistical package for social sciences
(SPSS/PS + V2.0). Base manual for the IBMPC/XT/AT and $P C / 2$. Chicago: SPSS Inc, 1988.

31 Remington RD, Schork MA. Statistics with application to the biological and health sciences. Englewood Cliffs: the biological and health scic

32 Schor SS. Fundamentals of biostatistics. New York: GP Putnam, 1986:174

33 Herbert R, Marcus M, Wolff MS, Perera FP, Andrews L, Godbold $\mathrm{JH}$, et al. Detection of adducts of deoxyribonucleic acid in white blood cells of roofers by P-postlabeling. Scand f Work Environ Health 1990;16:135-43.

34 Verma DK, Muir DCF, Cunliffe S, Julian JA, Vogt JH, Rosenfeld J. Polycyclic aromatic hydrocarbons in Ontario foundry environments. Ann Occup Hyg 1982;25 17-25.

35 Bjorseth A, Becher G. PAH in work atmospheres: Occurance and Determination. Florida: CRC-press, 1986: 117-39.

36 van Schooren FJ, van Leeuwen FE Hillebrand MJX, de Rijke M, Hart AAM, van Veen HG, et al. Determination of benzo(a)pyrene-diol epoxide DNA adducts in white blood cell DNA from cokeoven workers: the impact of smoking. I Natl Cancer Inst 1990;82:27-33.

37 Jongeneelen FJ, Anzion RBM, Theuws KL, Bos RP Urinary 1-hydroxypyrene levels in handling petroleum coke. F Toxicol Environ Health 1989;26:133-6.

38 Burgaz S, Borm PJA, Jongeneelen FJ. Evaluation of urinary excretion of 1-hydroxypyrene and thioethers in workers exposed to bitumen fumes. Int Arch Occup Environ Health 1992;63:397-401.

39 Ostenfeldt N. Mutagenic material in air pollution from the greater Copenhagen area. Copenhagen: Danish Environmental Protection Agency, 1989. (Working document No 11.)

40 Birdbord K, French JG. Carcinogenic and mutagenic risks associated with fossil fuels. In: Jones PW, Freudenthal R, eds. Carcinogenesis. Vol 3. New York: Raven Press, 1978:451-63 